\title{
Survival and growth performance of Heterobranchus bidorsalis larvae fed diet supplemented with e-probiotic III ${ }^{\circledR}$
}

\begin{abstract}
Background and Objective: Larvae survival problem has bed eviled catfish hatchery in Nigeria. This is widely attributed to many factors including poor utilization of feed at the early stage as swim up larvae. Probiotics is one important supplement in the diet of aquatic animals as immune stimulant, for prevention of disease and enhance survival. Experiment was conducted to establish if commercial probiotic (E-PROBIOTIC $111^{\circledR}$ ) will improve on the survival and growth of Heterobranchus bidorsalis larvae when added to the larvae feed and the influence on the intestinal microbial flora.
\end{abstract}

Materials and method: Two weeks old larvae weaned on decapsulated artemia were reared on $0.0,1.0,2.0$, and $3.0 \mathrm{~g} / \mathrm{kg}$ levels of E-probiotic $111^{\circledR}$ supplementedcommercial diet (Aqualis ${ }^{\circledR}$ fry powder) making up four dietary treatments allocated in triplicate in a completely randomized design. Survival, growth, and microbial constituent of larvae subjected to each treatment were monitored during a four weeks rearing.

Results: The results obtained indicated that there was no significant variation $(p>0.05)$ among the treatments with regards to survival rate. Larvae fed dietary treatments III $(2 \mathrm{~g} /$ $\mathrm{kg})$ and IV $(3.0 \mathrm{~g} / \mathrm{kg})$ had significantly $(p<0.05)$ increase in percent weight gain but with no significant variation $(p>0.05)$ in length increase. The water quality parameters monitored were not significantly different $(p>0.05)$ among the treatments and within recommended range for larvae survival.

Conclusion: It can be concluded that the supplementation of the E-probiotics 111 in the diets of the larvae enhanced the percent occurrence of gut beneficial Bacillus spp. at $2 \mathrm{~g}$ / $\mathrm{kg}$ of each which could have influenced the larvae better performance in terms of survival and growth.

Keywords: Heterobranchus bidorsalis, survival, growth, larvae, fry, probiotics, bacteria
Volume 9 Issue 3 - 2020

\section{MY Abubakar, JK Ipinjolu}

Department of Fisheries and Aquaculture, Usmanu Danfodiyo University, Nigeria

Correspondence: MY Abubakar, Department of Fisheries and Aquaculture, Usmanu Danfodiyo University, Nigeria,

Tel +2347033 I53 I 26, Email yahaya.abubakar@udusok.edu.ng

Received: April 15, 2020 | Published: May 18, 2020

\section{Introduction}

The transition from endogenous to exogenous feeding is a critical event in the life of a fish; it is generally acknowledged that the choice of food, during the first few days of hatching, is critical for larval survival. ${ }^{1}$ This survival problem has bedeviled catfish aquaculture in Nigeria. Mostly, it is widely attributed to many factors including poor utilization of feed at the early stage as swim up larvae. The need for feed additives or supplements with proven physiological benefits for the fishes which simultaneously provide protection against diseases, ${ }^{2}$ becomes imperative. Various research findings have show-case the use of different feed supplements in fish production, including, enzyme supplements, ${ }^{3}$ microbial feed supplements such as zooplankton, phytoplankton, fungi, yeast and bacteria, ${ }^{4}$ dietary immune stimulant additives, such as $\beta$-glucan, lactic acid bacteria, lipopolysaccharides, and protein hydrolysates. ${ }^{5}$ Probiotics is one important supplement in the diet of aquatic animals which, according to Abdelhamid et al., ${ }^{6}$ its application is increasing with the world demand for consumer and environmentally friendly aquaculture products. Probiotics are 'bio-friendly agents' such as lactic acid bacteria and Bacillus spp. that can be introduced into the culture environment to control and compete with pathogenic bacteria as well as to promote the growth of the cultured organisms. ${ }^{7}$ They are nonpathogenic and nontoxic microorganisms without undesirable side-effects when administered to aquatic organisms. ${ }^{7}$ According to Chelladurai et al,. ${ }^{8}$ the main strategy in use today is supplementation of the probiotic bacteria into the feed of immature fishes, in order to increase the growth parameters. There are reports of various studies on the use of probiotics in aquaculture. Such studies include the use for comparative exclusion of potential pathogenic organisms, ${ }^{9}$ stimulating precocious maturation of digestive system, ${ }^{10}$ as source of nutrients and enzymatic contribution to digestion guaranteeing improved use of the feed or enhancing its nutrition worth, ${ }^{6,10}$ to influence water quality by converting organic matter back to $\mathrm{CO}_{2}{ }^{11}$ and enhancement of immune response, host response toward malady, or by rising the quality of its close setting and antiviral effect on fish fry. ${ }^{12}$ Little or no information is available on the effect of probiotics on fry of hatchery bred economically important species of Nigerian aquaculture, one of which is Heterobranchus bidorsalis. There is the need for improvement in the production of $H$. bidorsalis in order to overcome the problem of inadequate seed for stocking fish farms. This informed the investigation into the survival and growth of $H$. bidorsalis fry in the hatchery using prepared starter diets and probiotics. This study therefore tried to establish the influence of

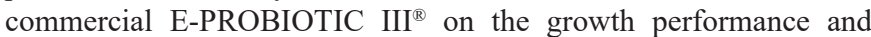
intestinal microbial flora of $H$. bidorsalis fry.

\section{Materials and methods}

This study was carried out at the Teaching and Research Fish Farm of the department of Fisheries and Aquaculture, Usmanu Danfodiyo 
University, Sokoto, Nigeria between July and August 2016. The site is on latitude $13^{\circ} 07^{\prime} 78^{\prime \prime} \mathrm{N}$ and longitude of $05^{\circ} 12^{\prime} 25^{\prime \prime} \mathrm{E}$ at $275 \mathrm{~m}$ above sea level. The site is located in the Dry Sub-Humid IllelaSokoto-Yelwa Plain of Nigeria, with agro-climate characterized by seven long dry months, occurring from October to April of every year, mean monthly maximum temperature of $31^{\circ} \mathrm{C}-40^{\circ} \mathrm{C}$ and mean monthly minimum temperature of $12^{\circ} \mathrm{C}-24^{\circ} \mathrm{C}$ and evapotranspiration of the order $1670 \mathrm{~mm}$. The area is characterized with cool dry air during the harmattan from November to February and hot season from March to

Table I Names and manufacturer of probiotics used in this study
May. Annual rainfall in the area ranged from 508 to $1016 \mathrm{~mm} /$ year. ${ }^{13}$ The mean relative humidity is $14.9 \%$ and $40 \%$ in March and June, respectively. ${ }^{13,14}$

\section{The probiotic}

The experiment was conducted to test the effect of the commercial probiotic on the survival and growth of $H$. bidorsalis larvae. The probiotic composition and the manufacturers detail are as presented in Table 1.

\begin{tabular}{|c|c|c|}
\hline Probiotics & Composition & Manufacturer \\
\hline E-PROBIOTICS III ${ }^{\circledR}$ & $\begin{array}{l}\text { - Bacillus subtilis: } 130 \text { million CFU/g. } \\
\text { - Yeast } \\
\text { - Pediococcusacidilactici: } 70 \text { million CFU/g } \\
\text { - Maifanite: } 100 \% \\
\text { - Total Viable Bacteria: } \geq 200 \text { million CFU/g }\end{array}$ & Shangdong Baolai-Leelai Bio-Tech. Co. Ltd. China \\
\hline
\end{tabular}

\section{Fish larvae}

Larvae of the fish weaned from decapsulated Artemiaas starter feed for two weeks, were subjected to feeding trial to test the effect of different E-probiotics $111^{\circledR}$ supplementation levels on larvae survival, growth and feed utilizationto test for effect of probiotics on the survival and growth of the hatchlings.

\section{Experimental design}

The experiment using E-probiotics $111^{\circledR}$ was carried out in 12 experimental units (70litres capacity plastic bowls filled with clean water and fitted with mechanical aerator). Two hundred (200) fry were randomly sampled and stocked in each experimental unit. Diets (Aqualis ${ }^{\circledR}$ fry powder) supplemented with varying levels of E-probiotics $111^{\circledR}(0.0,1.0,2.0$, and $3.0 \mathrm{~g} / \mathrm{kg})$ which make up the dietary treatments which were allocated in triplicate and make up to 4 experimental treatments arranged in completely randomized design.

\section{Experimental diets}

The experimental diets consisted of granules of Aqualis ${ }^{\circledR}$ fry powder, which was fed to the hatchlings for 14 days, and subsequently changed to crumbles $(1.0 \mathrm{~mm})$ and fed to the hatchlings for another 14 days. The commercial probiotics E-probiotics $111^{\circledR}$ was introduced into the diets at the varying levels of inclusion $(0.0,1.0,2.0$, and $3.0 \mathrm{~g} /$ $\mathrm{kg}$ each) that served as dietary treatment levels. The larvae were fed to satiation three (3) times daily. To ensure efficient utilization of the probiotics, the quantity of probiotics required per treatment was measured and mixed with the basal feed granules. At every feeding time, the powdery mixture was made into paste and served to the fry.

\section{Measurement of experimental fish}

The initial weight of the fish for each of the experimental units were measured using JT $210 \mathrm{~N}$ series electronic top loading balance of two digits and the total length was measured using a plastic tape rule $(\mathrm{mm})$. This was done by quickly taking the larvae out of water by siphoning into a bowl after which they were counted directly using a plastic hose via siphoning. The fry were then put in alinen cloth and transferred into a pre-weighed container using feather and then weighed on the balance. The lengths of ten (10) fry randomly collected from the container were measured using a plastic transparent ruler graduated in millimeters.

\section{Experimental management}

Feeding was done three (3) times daily, in the morning (8:00am), afternoon $(1: 30 \mathrm{pm})$, and evening $(6: 30 \mathrm{pm})$. Feed remains were siphoned out of the culture medium every morning before feeding, and same quantity of water removed during siphoning were replaced immediately. Total renewal of whole water in the bowls was done every two days, and the bowls bottoms was scrubbed to remove dirt. The bowls were supplied with oxygen using Resun Air Pump (Model ACO-008-Aquarium Aquatic DC-160 Guanzhou Fischer Chemical Co., Ltd.).

\section{Assessment of growth and mortality}

The survival and mortality were monitored on daily basis. The weight and the total length of the hatchlings in each experimental unit was taken at intervals of 7 days. On sampling and weighing days, the fry from each unit were collected in a plastic sieve and then allowed to drain by placing the sieve on a foam to soak to prevent fry from being weight with water, and then place on the weighing balance. Total length of fry was measured using a plastic ruler.

\section{Water quality monitoring}

Five water quality parameters (temperature, $\mathrm{pH}$, dissolved oxygen, ammonia and conductivity) were determined daily during the feeding experiment. These parameters were determined for each of the treatments. The temperature was determined with the aid of mercury in glass thermometer which ranges from $0^{\circ} \mathrm{C}$ to $100^{\circ} \mathrm{C}$, calibrated at $1^{\circ} \mathrm{C}$ interval. The thermometer was immersed into the water in the culture tanks for a period of time sufficient to permit complete equilibration, and the mercury level was read as water temperature. The $\mathrm{pH}$ was determined with the aid of a $\mathrm{pH}$ meter (Jenway ${ }^{\circledR}$ 13015-England). The dissolved oxygen was determined by using the Winkler's azide titrimetric method. Conductivity was measured using Adwa AD32 EC/TDS Digital meter (6726 Szeged-Hungary).

\section{Intestinal microbial flora analysis}

\section{Fish samples collection}

Fingerlings of $H$. bidorsalis weaned from starter diets were analyzed as the initial before the probiotic application experiment. Three (3) fingerlings were collected from each experimental unit. 
They were taken live to the Microbiology Laboratory of the Usmanu Danfodiyo University, Sokoto for analysis.

\section{Preparation of stock cultures}

Each fish was dissected; the gut removed by means of a sterile scalpel and pair of scissors, and kept in a clearly labeled sterile Petri dish. Each of the gut was pounded with mortar and pestle. Homogenization was carried out to obtain uniform distribution of cells through stock culture.

\section{Enumeration, isolation and identification of bacteria}

Six serial dilutions of the original stock culture from the intestine were prepared. Each dilution was placed on solidified freshly prepared nutrient agar and spread using a sterile glass rod and incubated at $37^{\circ} \mathrm{C}$ for 24 hours after which the colonies that developed on the plates were counted. Those counts within 30-300 colony forming units (cfu) were reported as total viable count (TVC). Distinct colonies from each plate were then picked by means of a sterile wire loop and sub cultured on to a freshly prepared nutrient agar medium contained in sterile plates. This was done with a view to obtaining pure culture of the growth. The plates were incubated at $37^{\circ} \mathrm{C}$ for 24 hours. Characterization of the pure isolates was performed and involved colonial characteristics, cell micro morphology, motility test and biochemical test of gram reaction, catalase test, glucose, sucrose and lactose utilization, citrate test, motility test, indole test, urease test, hydrogen sulfide production, gas production, methyl red test, vogepraskaure test, coagulase test and spore staining. These tests were done to identify isolates to generic level. ${ }^{15}$

\section{Data analysis}

\section{Survival and growth indices}

Care of hatchlings started from the moment the eggs began to hatch. Separation of fry from the deformed larvae and general sanitation were carried out by siphoning using a rubber hose.

\section{Percent survival rate (S)}

The percent survival rate was computed as follows ${ }^{16}$

$$
S(\%)=\frac{N_{i}}{N_{o}} \times 100
$$

Where, $\mathrm{N}_{\mathrm{o}}=$ number of fry stocked at the beginning of the experiment.

$\mathrm{N}_{\mathrm{i}}=$ number of fry alive at the end of the experiment.

Weight gain (WG)

The weight gain was computed as follows ${ }^{17}$ :

$W G=$ Final weight $(g)$ - Initial weight $(g)$

\section{Percent weight gain (PWG)}

This was calculated as follows ${ }^{17}$ :

$$
P W G=\frac{\text { Final weight }(g)-\text { Initial weight }(g)}{\text { Initial weight }} \times 100
$$

\section{Specific growth rate (SGR)}

This was calculated from the following equation given below ${ }^{18}$

$$
S G R \%=\frac{\log _{e} w_{f}-\log _{e} w_{i}}{\text { Time (days) }} \times 100,
$$

Where, $\log _{\mathrm{e}}=$ Natural logarithm

$\mathrm{W}_{\mathrm{i}}=$ initial weight $(\mathrm{g})$ of fish at the beginning of experiment.

$\mathrm{W}_{\mathrm{f}}=$ final weight $(\mathrm{g})$ of fish at the end of the experiment.

Percent Length Increase

$P L I(\%)=\frac{\text { Final length }(\mathrm{mm})-\text { Initial length }(\mathrm{mm})}{\text { Initial length }(\mathrm{mm})} \times 100$

\section{Condition factor (K)}

Condition Factor $(\mathrm{K})$ of the fry was calculated at the beginning and at the end of the experiment following the procedure of Bagenal and Tesch. ${ }^{19}$

$$
K=\frac{100 W}{L^{3}},
$$

Where, $\mathrm{W}=$ weight of fish $(\mathrm{g})$

$\mathrm{L}=$ total length of fish $(\mathrm{cm})$.

\section{Statistical analysis}

Data collected on growth, survival, feed utilization and intestinal microflora were subjected to analysis of variance (ANOVA) and means were separated using New Duncan's Multiple Range Test (DMRT).$^{20}$ Computer analysis was carried out using the SPSS V: 20.0 package (IBM-SPSS Statistics 20) for windows.

\section{Results}

\section{Survival and growth performance.}

The results on the survival and growth of fish larvae placed on E-probiotics 111 supplemented diet are presented in Table 2. There was no significant variation $(p>0.05)$ among the treatments with regards to survival rate. However, it was observed that larvae fed dietary treatment III ( $2 \mathrm{~g}$ probiotic/kg of feed), had the highest survival rate when compared to other treatments right from the first week to the end of the trial (Figure 1). The effects of dietary treatments on growth parameters such as mean weight gain (WG), mean percent weight gain (PWG), mean specific growth rate (SGR), and mean length increase are presented in Table 2. Larvae fed with diet III ( $2 \mathrm{~g}$ probiotic/kg of feed), had the highest WG $(289.52 \pm 19.54)$ but was not significantly different $(p>0.05)$ when compared with group fed TRT IV (3g probiotic/kg of feed). However, both exhibited significantly $(\mathrm{P}<0.05)$ higher WG than larvae fed diets II $(201.71 \pm 18.68)$ and I $(196.49 \pm 24.85)$ which were not significantly $(p>0.05)$ different from each other. This is also evident in Figure 2 where larvae fed dietary treatments III and IV peaked higher at the 3rd and 4th week than those on dietary treatments I and II. The results of the PWG and SGR followed similar pattern as the weight gain. 
Table 2 Survival and growth indices of Heterobranchusbidorsalis larvae fed varying levels of E-Probiotic III for 28-days

\begin{tabular}{|c|c|c|c|c|}
\hline \multirow[b]{2}{*}{ Parameter } & \multicolumn{4}{|c|}{ Treatment/(g) probiotics/(kg) feed } \\
\hline & I (0g/kg) & II(Ig/kg) & $\mathrm{III}(2 \mathrm{~g} / \mathbf{k g})$ & IV(3g/kg) \\
\hline Initial fish number & 600 & 600 & 600 & 600 \\
\hline Final fish number & 225 & 281 & 334 & 250 \\
\hline Survival rate (\%) & $37.50 \pm 3.55$ & $46.83 \pm 2.96$ & $55.67 \pm 8.92$ & $41.66 \pm 5.89$ \\
\hline Initial body weight (mg) & 11.95 & 11.95 & 11.95 & 11.95 \\
\hline Final body weight (mg) & $208.44 \pm 24.85^{b}$ & $213.66 \pm 18.68^{b}$ & $301.47 \pm 19.54^{\mathrm{a}}$ & $335.14 \pm 10.79^{a}$ \\
\hline Weight gain (mg) & $196.49 \pm 24.85^{b}$ & $201.71 \pm 18.68^{b}$ & $289.52 \pm 19.54^{a}$ & $232.19 \pm 10.79^{a}$ \\
\hline Weight gain (\%) & $1644.27 \pm 207.98^{\mathrm{b}}$ & $1687.92 \pm 156.28^{b}$ & $2422.74 \pm 163.52^{\mathrm{a}}$ & $2704.53 \pm 190.32^{\mathrm{a}}$ \\
\hline Specific growth rate (\%/day) & $10.15 \pm 0.46^{\mathrm{b}}$ & $10.27 \pm\left. 0.3\right|^{b}$ & $11.51 \pm 0.23^{\mathrm{a}}$ & $11.90 \pm 0.12^{\mathrm{a}}$ \\
\hline Initial body length (mm) & $9.13 \pm 0.09$ & $9.07 \pm 0.12$ & $9.13 \pm 0.09$ & $9.03 \pm 0.12$ \\
\hline Final body length (mm) & $28.67 \pm 4.37$ & $31.33 \pm 4.06$ & $30.00 \pm 4.04$ & $28.67 \pm 2.40$ \\
\hline Length increase (mm) & $19.53 \pm 4.45$ & $22.27 \pm 4.14$ & $20.87 \pm 4.01$ & $19.63 \pm 2.41$ \\
\hline Length increase (\%) & $214.75 \pm 50.12$ & $246.61 \pm 47.83$ & $228.26 \pm 43.34$ & $217.49 \pm 26.95$ \\
\hline Condition factor (k) & $1.33 \pm 0.80$ & $0.82 \pm 0.28$ & $1.54 \pm 0.82$ & $1.58 \pm 0.47$ \\
\hline
\end{tabular}

Mean values in row with same letter are not significantly different $(p>0.05)$

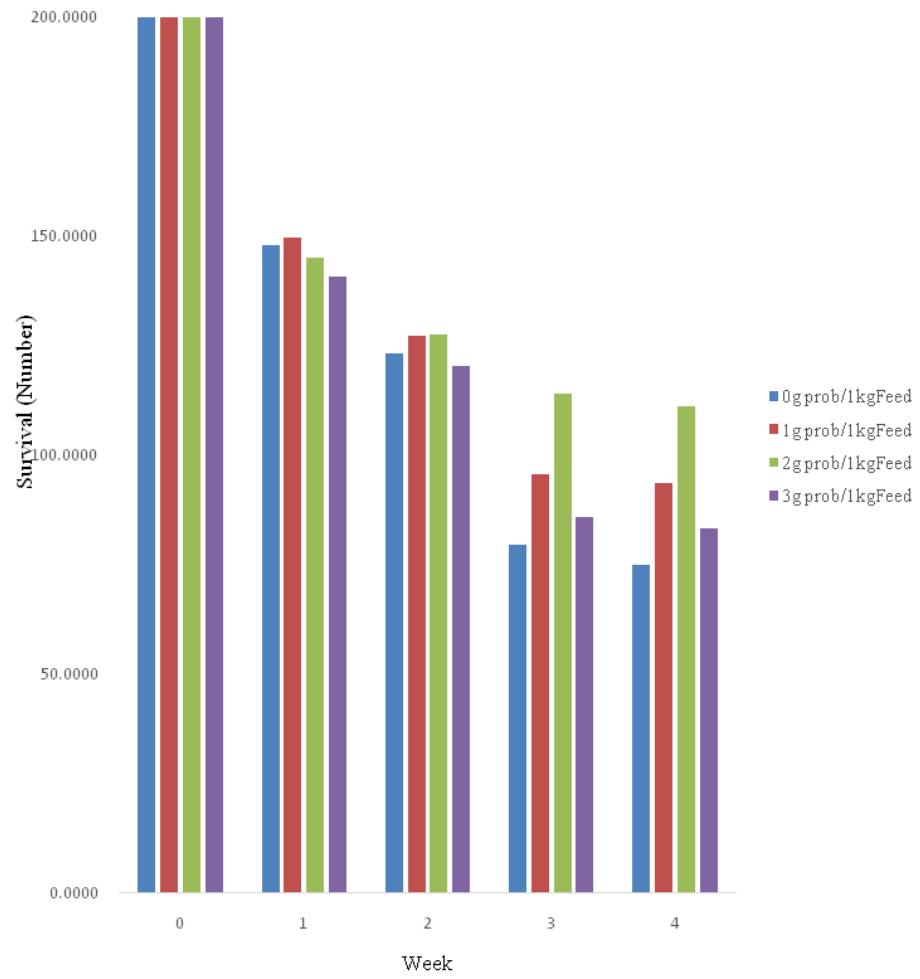

Figure I Survival of $H$. bidorsalis larvae reared on diets supplemented with different levels of E-Probiotics III. 


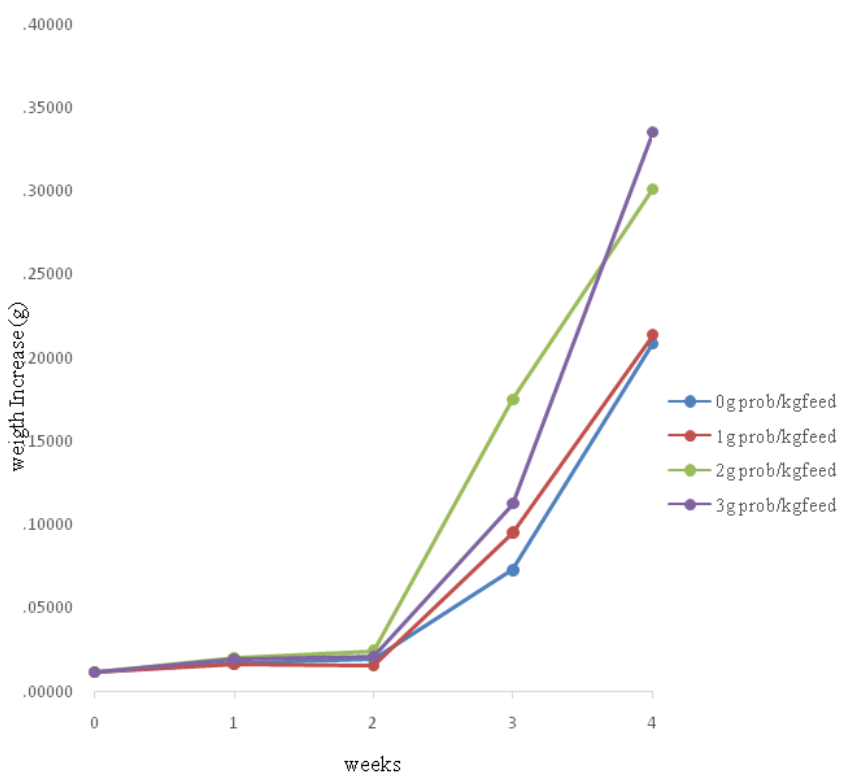

Figure 2 Growth of heterobranchus bidorsalis fed diet supplemented different levels of E-probiotics III.

The length increase and percent length increase obtained in larvae subjected to the four different dietary treatments were not significantly different $(\mathrm{P}>0.05)$ however those subjected to dietary TRT II were numerically higher $(22.27 \pm 4.14)$ and $(246.61 \pm 47.83)$ respectively. The condition factor was also observed not to be $(p>0.05)$ significantly different among the four dietary treatments and ranged from $0.82 \pm 0.28$ in dietary treatment II to the highest $(1.58 \pm 0.47)$ in dietary treatment IV.

\section{Water quality parameters}

The results of the water quality parameters (temperatures, $\mathrm{pH}$, dissolved oxygen and ammonia) during the period of the E-probiotic
111 experiment are presented in Table 3 . The minimum temperature $\left(27.5^{\circ} \mathrm{C}\right)$ recorded was in the morning and evening while the maximum was at afternoon $\left(32.5^{\circ} \mathrm{C}\right)$. However, the overall mean temperature was $29.43 \pm 0.35$. The $\mathrm{pH}$ varied from 7.28 to 8.29 with a mean of $7.92 \pm 0.09$. The overall mean dissolved oxygen value was $4.66 \pm 0.19$ with minimum and maximum values of 4.20 and 5.19, respectively. There was no significant difference in the dissolved oxygen among the treatments. The overall mean value recorded for ammonia was $0.0092 \pm 0.01$ with a minimum value of 0.0088 and maximum of 0.0096 , and there was no significant difference in the ammonia concentrations among the treatments.

Table 3 Mean water quality parameter measured during E-Probiotic II I experimental period

\begin{tabular}{llll}
\hline Parameter & Mean & Minimum & Maximum \\
\hline Temperature $\left({ }^{\circ} \mathrm{C}\right)$ & & & \\
Morning & $28.6 \pm 0.22$ & 27.5 & 29.9 \\
Afternoon & $30.3 \pm 0.39$ & 28.0 & 32.5 \\
Evening & $29.4 \pm 0.44$ & 27.5 & 32.0 \\
Overall mean & $29.43 \pm 0.35$ & 27.7 & 31.5 \\
Ph & $7.92 \pm 0.09$ & 7.28 & 8.29 \\
Dissolved Oxygen $(\mathrm{mg} / \mathrm{l})$ & & & \\
TRT I & $4.49 \pm 0.26$ & 4.21 & 5.00 \\
TRT II & $4.66 \pm 0.14$ & 3.96 & 5.06 \\
TRT III & $4.67 \pm 0.23$ & 4.32 & 5.11 \\
TRT IV & $4.83 \pm 0.11$ & 4.62 & 5.30 \\
Overall mean & $4.66 \pm 0.19$ & 4.20 & 5.19 \\
Ammonia $(\mathrm{mg} / \mathrm{l})$ & & & \\
TRT I & & 0.0086 & 0.0097 \\
TRT II & $0.0092 \pm 0.002$ & 0.0084 & 0.0098 \\
TRT III & $0.0090 \pm 0.002$ & 0.009 & 0.0093 \\
TRT IV & $0.0089 \pm 0.00$ I & 0.0087 & 0.0097 \\
Overall mean & $0.0096 \pm 0.000$ & 0.0095 & 0.0096 \\
\hline
\end{tabular}


The results of microbial load in the gut of the larvae subjected to E-Probiotics 111 test are shown in Table 4. The highest mean total viable count (TVC) of bacterial isolates is from larvae fed diet II (1g probiotics $/ \mathrm{kg}$ of feed) with a value of $15.3 \times 10^{5}\left(\mathrm{cfug}^{-1}\right)$ and a range of $3.0 \times 10^{5}$ to $31.0 \times 10^{5}$. This was followed by those fed the control diet with mean $14.8 \times 10^{5}\left(\mathrm{cfug}^{-1}\right)$ and a range of $1.4 \times 10^{5}$ to $41.0 \times 10^{5}$ while the least count of $11.3 \pm 0.5 \times 10^{5}\left(\mathrm{cfug}^{-1}\right)$ was obtained in the gut of fish fed diet III ( $2 \mathrm{~g}$ probiotics $/ \mathrm{kg}$ of feed).

Table 4 Mean number of cells ( $\left.\mathrm{g}^{-1} \mathrm{CFU}\right)$ in the gut of $H$. bidorsalis 28 days after feeding with Aqualis commercial diets supplemented with E-probiotics II

\begin{tabular}{llll}
\hline Treatment & \multicolumn{3}{l}{ Bacterial count in (cfu/g) } \\
\hline & Mean total count & Min & Max. \\
\hline Initial & $4.3 \pm 0.6 \times 10^{5}$ & $3.0 \times 10^{5}$ & $5.0 \times 10^{5}$ \\
TRT I (Control) & $14.8 \pm 1.3 \times 10^{5}$ & $1.4 \times 10^{5}$ & $41.0 \times 10^{5}$ \\
TRT II (Ig probiotics $/ \mathrm{kg}$ of feed) & $15.3 \pm 0.8 \times 10^{5}$ & $3.0 \times 10^{5}$ & $31.0 \times 10^{5}$ \\
TRT III (2g probiotics $/ \mathrm{kg}$ of feed) & $11.3 \pm 0.5 \times 10^{5}$ & $4.0 \times 10^{5}$ & $21.0 \times 10^{5}$ \\
TRT IV (3g probiotics $/ \mathrm{kg}$ of feed) & $12.0 \pm 0.7 \times 10^{5}$ & $4.0 \times 10^{5}$ & $26.0 \times 10^{5}$ \\
\hline
\end{tabular}

Table 5 Frequency of occurrence of bacterial isolates

\begin{tabular}{lllll}
\hline Bacterial isolates & $\begin{array}{l}\text { Frequency } \\
\text { of occurrence }\end{array}$ & \% occurrence & $\begin{array}{l}\text { \% } \\
\text { Bacterial type }\end{array}$ \\
\hline Bacillus firmus & 3 & 17.65 & Bacillus spp. & 58.8 \\
Bacillus laterosporus & 2 & 11.76 & & \\
Listeria monocytogenes & 3 & 17.65 & Other bacterial & 41.2 \\
Micrococcus kristanae & 2 & 11.76 & & \\
Bacillus lentus & 1 & 5.89 & & \\
Kurthia spp & 2 & 11.76 & \\
Bacillus subtilis & 4 & 23.5 & 100 & \\
Total & 17 & & \\
\hline
\end{tabular}

Table 6 indicated the biochemical characterization used to identify the bacterial species isolated. The results from the gram staining revealed that the larvae subjected to all the dietary treatments harbored gram-positive rod (gram+ve) bacterial isolates. Bacillus spp. dominance was observed in the gut of the larvae fed diet containing ( $3 \mathrm{~g}$ probiotics $/ \mathrm{kg}$ of feed) followed by those fed dietary treatments II ( $1 \mathrm{~g}$ probiotics $/ \mathrm{kg}$ of feed) and III ( $2 \mathrm{~g}$ probiotics $/ \mathrm{kg}$ of feed) the least occurred in treatment I (control).

\section{Discussion}

This result of feeding H. bidorsalis with E-Probiotics 111 corroborates with earlier findings. ${ }^{21,22,1}$ The higher survival obtained in dietary probiotics supplemented treatments could be attributed to the colonization of the bacillus bacteria in their guts and hence tend to reduce disease causing bacterial.

The better growth rate (weight gain, specific growth rate and percent weight gain) observed in larvae fed dietary treatments III $(2 \mathrm{~g} / \mathrm{kg})$ and IV $(2 \mathrm{~g} / \mathrm{kg})$ of E-Probiotics 111 with increased levels of probiotics supplement in the present study confirm the results from other studies that the incorporation of probiotic in the diets can improve growth performance. ${ }^{23-27}$
Table 5, contained the frequency of occurrence of bacterial isolates in the guts of larvae fed to different treatments of E-Probiotics 111. Seventeen (17) bacteria species were encountered of which Bacillus subtilis had the highest occurrence (23.5\%), followed by Bacillus firmus and Listeria monocytogenes with 17.65\%. However, Bacillus lentus had the least (5.89\%). The Bacillus spp. accounted for $58.8 \%$ while other bacterial species scored $41.2 \%$.
This could also be due to improvement in the intestinal microbial flora balance with bacterial of the genus bacillus spp. having highest frequency of occurrence which, in turn, could result to better absorption quality, increased enzyme activities and growth. ${ }^{28}$ This finding confirms the assertion of Verschuere et al., ${ }^{12}$ that probiotics have useful effects for host by producing enzymatic materials, competing for chemical materials absorption and adhesion in digestive system. Bacillus bacterial are not dominant in the normal intestinal microbiota of fish as in homeotherms but their population can be maintained artificially at a high level by regular intake of food that give positive results. ${ }^{12}$ The normal interaction between probiotics and their host is known to be a symbiotic relation, and affect the intestinal ecosystem by stimulating mucosal immune mechanisms through competition with pathogenic microorganisms. Non digestible nutrients including dietary fibers in the feed are further fermented by the available probiotics in large intestine and thus producing oligo-compounds as well as simple molecules including fatty acids, which improve their uptake and enhance the growth. ${ }^{21,27}$ The non-significance in growth recorded between larvae fed control treatment I $(0 \mathrm{~g} / \mathrm{kg})$ and dietary treatment II $(1 \mathrm{~g} / \mathrm{kg})$ could be due to the low dose of the probiotic applied compared to those with higher doses. 


\section{Conclusion}

This showed that different levels of the E-Probiotics 111 could cause different effects on growth parameters in H. bidorsalis larvae. With better growth in larvae fed E-probitic 111 at $2 \mathrm{~g} / \mathrm{kg}$ and $3 \mathrm{~g} / \mathrm{kg}$ of basal feed. Supplementation of the E-probiotics 111 in the diets of the larvae enhanced the percent occurrence of gut beneficial Bacillus spp. at $2 \mathrm{~g} / \mathrm{kg}$ of feed which could have influenced the larvae performance in terms of survival and growth.

\section{Significant statement}

The study discovered larvae Heterobranchus bidorsalis survive and grow better when the diet provided is supplemented with E-Probiotics 111 at $2 \mathrm{~g} / \mathrm{kg}$ of larvae compounded commercial feed. This is against the odds and believe that Heterobranchus bidorsalis do not survive well in hatcheries. This has provided a way of improving larvae survival in hatcheries around the study area.

\section{Conflicts of interest}

The author declares that there is no conflicts of interest.

\section{Funding}

None.

\section{Acknowledgment}

None.

\section{References}

1. Adewumi AA, Olaleye VF. Catfish culture in Nigeria: progress, prospects and problems. African Journal of Agricultural Research. (2011);6(6):1281-1285.

2. Ibrahem MD. Evolution of probiotics in aquatic world: Potential effects, the current status in Egypt and recent prospectives. Journal of Advanced Research. 2015;6:765-791.

3. Hardy RW. New developments in aquatic feed ingredients, and potential of enzyme supplements. In: Cruz -Suárez LE, Ricque-Marie, D, TapiaSalazar M, Olvera-Novoa MA. y Civera-Cerecedo R, editors. Avances en Nutrición Acuícola V. Memoriasdel V Simposium Internacional de Nutrición Acuícola. Mérida, Yucatán, Mexico. 2000. p. 19-22

4. Banerjee S, Azad SA, Vikineswary S, et al. Phototrophic bacteria as fish feed supplement. Asian-Aus. J Anim Sci. 2000;13(7):991-994.

5. Murray AL, Pascho RJ, Alcorn SW, et al. Effects of various feed supplements containing fish protein hydrolysate or fish processing by-products on the innate immune functions of juvenile coho salmon (Oncorhynchus kisutch). Aquaculture. 2003;220(1-4):643-653.

6. Abdelhamid AM, AI Mehrin MI, El-Barbary, et al. Evaluation of a new Egyptian probiotic on African catfish fingerlings. Journal of Environmental Science and Technology. 2009;2(3):133-145.

7. Farzanfar A. The use of probiotics in shrimp aquaculture Federation of European Microbiological Societies (FEMS) Published by Blackwell Publishing Ltd. Immunol Med Microbiol. 2006;48(2):149-158.

8. Chelladurai G, Jebaraj F, Rathinasami N. Protective effect of probiotic diets on haematobiochemical and histopathology changes of Mystusmontanus(Jerdon 1849) against Aeromonas hydrophila. Journal of Coastal Life Medicine. 2013;1(4):259-264.
9. Wache Y, Auffray F, Gatesoupe FJ, et al. Cross effects of the strain of dietary Saccharomyces cerevisiae and rearing conditions on the onset of intestinal microbiota and digestive enzymes in rainbow trout, Onchorhynchus mykiss fry. Aquaculture. 2006;258(1-4):470-478.

10. Bagheri T, Seyed Aliakbar H, Vahid Y, et al. Growth, survival and Gut Microbial Load of Rainbow Trout (Onchorhynchus mykiss) fry given diet supplemented with probiotic during the two months of first feeding. Turkish Journal of Fisheries and Aquatic Sciences. 2008;8:43-48.

11. Padmavathi P, K Sunitha, Veeraiah K. Efficacy of probiotics in improving water quality and bacterial flora in fish ponds. African Journal of Microbiology Research. 2012;6(49):7471-7478.

12. Verschuere L, Rombaur G, Soogerloos P. Probiotic bacteria as biological control agents in aquaculture. Microbiol Mol Biol Rev. 2000;4(64):655-671.

13. Ojanuga AG. Agro ecological zones of Nigeria Manual. National Special Programme for Food Security and FAO. 2006. 124 p.

14. Mamman AB. Nigeria: A people United, A Future Assured (Sokoto State). Gabumo publishing Co. Ltd., Lagos Nigeria. 2000. 298 p.

15. Cheesbrough M. District laboratory practice in tropical countries. Parts 2 published by Cambridge University Press. 2000. 13-7 p.

16. Ayinla OA, Nwadukwe FO. Effect of season on controlled propagation of the African Catfish, Clariasgariepinus (Burchel 1822). Nigerian Institute for Oceanography and Marine Research Technical Paper No. 62. $1990 ; 15 \mathrm{p}$

17. Sveier H, Raae AJ, E. Lied. Growth and protein turnover in Atlantic salmon (Salmo salar L.); the effect of dietary protein level and protein particle size. Aquaculture. 2000;185(1-2):101-120.

18. Castell JD, Tiews K. Report of the EIFAC, IUNS and ICES working group on the standardization of methodology in fish nutrition research. Technical Paper. 1980;36:24p.

19. Bagenal TB, Tesch FW. Fecundity. In: Methods for the Assessment of Fish Production in Fresh Waters. Bagenal TB, 3rd edn. Blackwell scientific Publications. 1987; p. 93-123.

20. Gomez KA, Gomez AA. Statistical procedure for Agricultural Research. 2nd Edn. New York: John Wily and sons, 1984; p. 680.

21. Vieira FN, Buglione CC, Mourino JPL, et al. Effect of probiotic supplemented diet on marine shrimp survival after challenge with Vibrio harveyi. Arq Bras Med Vet Zootecv. 2010;62(3):631-638.

22. Jha DK, RC Bhujel AK. Anal Dietary supplementation of probiotics improves survival and growth of Rohu (Labeorohita Ham.) hatchlings and fry in outdoor tanks. Aquaculture. 2015;435:475-479.

23. Singh RK, Chavan JB, Vartak VR. Effect of a probiotic bacterium supplemented feed on survival and growth of fry of two ornamental fishes, Pterophyllumscalare and Metynnisschreitmuelleri. Indian J. Fish. 2003;50(1):35-39.

24. El-Haroun, Goda E, R.AMAS, Kabir Chowdury MA. Effect of dietary probiotic Biogen supplementation as a growth promoter on growth performance and feed utilization of Nile tilapia Oreochromis niloticus(L.). Aquacult Res. 2006;37(14):1473-1480.

25. Gatesoupe FJ. The effect of three strains of lactic bacteria on the production rate of rotifers Brachionus plicatilis and their dietary value for larval turbot Scophtalmus maximus. Aquaculture. 1991;96(3-4):335-342.

26. Ghosh S, Sinha A, Sahu C. Effect of probiotic on reproductive performance in female live bearing ornamental fish. Aquacult Res. 2007;38: 518-526. 
27. Lara-Flores MLC, Olivera-Castillo, Olvera-Novoa MA. Effect of the inclusion of a bacterial mix (Streptococcus faecium and Lactobacillusacidophilus), and the yeast (Saccharomycescerevisiae) on growth, feed utilization and intestinal enzymatic activity of Nile tilapia (Oreochromisniloticus). Int J Fish Aquacult. 2010;2:93-101.
28. Ringo E, Birkbeck TH. Intestinal microflora of fish larvae and fry. Aquaculture Research. 1999;30:73-93 